\title{
不整脈治療の進歩
}

日本大学医学部小览科学系小児科学分野

住友 直方

\section{Historical Review and Advancement of Arrhythmia Therapy}

\author{
Naokata Sumitomo \\ Department of Pediatrics and Child Health, Nihon University School of Medicine, Tokyo, Japan
}

不整脈の診断，治療の歴史について述べたいと思う。心電図は 1903 年にオランダの生理学者 Willem Einthoven の発明した galvanometerにより記録された，彼はこの業績により1924 年にノーベル医学賞を受賞している，当時 の記録原理は現在でも使用されており，Einthovenの三角として，彼の名前は残されている。1906 年の Einthoven による心房細動，Finny JMによる徐脈心電図の記録が，不整脈診断の最初である。1909 年に Mackenzieがジギ夕 リスの効果を唱え, 以後, 1910 年代からキニジン, 1950 年代にプロカインアミド, 1960 年代にはプロプラノロル， リドカイン，ジフェニルヒダントイン，ベラパミルなどが次々に使用されるようになった。 1970 年には VaughanWilliams 分類が発表され，1980 年代にはアミオダロン，フレカイニド，プロパフェノンなどが使用されるように なり，抗不整脈剤が治療の主流となった。しかし，1989年にCAST studyにより，急性心筋梗塞患者に対して Ic 群抗不整脈剂が心室期外収縮を抑制していたにも関わらず，死亡率を増加させることが報告された。抗不整脈剂 には催不整脈作用や陰性変力作用があり，不整脈抑制が，生命予後の改善にはつながらない，エビデンスに基づ き治療を考えるべきである，など大きな反省の時期に入った，そこでSicilan Gambit 会議が 1990 年代後半から開 かれ，薬物治療はこれまでの盲目的，経験的な治療から，より理論的ないしは病因に則した治療や， upstream 治 療へと選択肢が向けられるようになった.

一方，1982 年に Gallagher 等によりカテーテルからの直流通電による房室ブロック作成の報告以来，種々の不 整脈に対しカテーテルアブレーションが行われるようになった，1980 年代後半には高周波を用いた，より安全な カテーテルアブレーションが行われるようになり, 1990 年後半からはCARTO, EnSite といった $3 \mathrm{D}$ マッピングシ ステムが開発され，さらに診断，治療成績が向上した．

デバイス治療に関しては，古くから徐脈性不整脈に対するペースメーカ植え込みが行われていたが，1980 年代 には植込み型除細動器 (ICD) が使用されるようになり，2000 年からは心室再同期療法 (CRT), 両室ペーシング機 能付植込み型除細動器 (CRT-D)などが使用されるようになり，心臟突然死の減少に貢献している.

除細動器に関しては，1947 年にClaude Beckが，ヒトの心室細動に対する電気的除細動に成功しており，その 後 1979 年に自動体外式除細動器 (Automated External Defibrillator, AED) が報告され，それ以後小型化が進み，安 全性，操作性が向上した。1995 年，米国循環器学会 (American Heart Association, AHA) は院外で発症したSCA か らの生存率向上を目指して, 市民救助者による AED 使用を推奨している. 現在, 多くの学校に AED は設置され, 学校での心臟突然死の予防に役立っている.

これらの治療の進歩に平行して，QT 延長症候群に対する遺伝子診断，原因チャネル遺伝子およびその調節遺 伝子の解明は，遺伝性不整脈の概念を大きく恋えることとなる。これ以後 Brugada 症候群，カテコラミン誘発多 形性心室頻拍, QT 短縮症候群，進行性心臟伝導障害，特発性心室細動，など遺伝子異常の解明された不整脈は 数多い.

今後, 遺伝子治療など新たな治療法の開発が行われるようになる日も来るであろう. 小児循環器医としても, これら不整脈診断，治療の進歩に目を向け，小児の突然死予防に貢献することが必要と考える. 